\title{
Nitric Oxide Synthase Inhibitors Attenuate Phencyclidine-Induced Disruption of Prepulse Inhibition
}

Jenny L. Wiley, Ph.D.

Glutamate stimulation of N-methyl-D-aspartate (NMDA) receptors results in release of nitric oxide which may mediate the effects of NMDA receptor stimulation and/or may result in feedback inhibition of the presynaptic neuron. Results of a previous study showed that nitric oxide synthase (NOS) inhibitors blocked dizocilpine-induced behavior in mice. In the present study, NOS inhibitors were tested in combination with phencyclidine (PCP), a drug which typically dose-dependently disrupts prepulse inhibition of the acoustic startle response in rats. Alone, NOS inhibitors and promoters do not affect prepulse inhibition; however, when tested in combination with PCP, the NOS inhibitors, L-NOARG, 7-nitroindazole and arcaine - but not the NR2B-selective polyamine site NMDA antagonist, eliprodil-attenuated $P C P$-induced disruption of prepulse inhibition of the acoustic startle response. These effects are similar to those produced by many atypical antipsychotics and suggests that this class of drugs should be investigated further for their potential utility as antipsychotics and as treatments for PCP abuse. [Neuropsychopharmacology 19:86-94] (C) 1998 American College of Neuropsychopharmacology. Published by Elsevier Science Inc.
KEY WORDS: Antipsychotics; Nitric oxide synthase inhibitors; NMDA antagonists; Phencyclidine;

\section{Schizophrenia}

Nitric oxide is a soluble gas that is synthesized from the amino acid L-arginine by nitric oxide synthase (NOS). Nicotinamide-adenine dinucleotide phosphate-diaphorase (NADPH) is a required co-factor and citrulline is a co-product of the reaction. Constitutive and inducible forms of NOS have been identified, but it is the constitutive, $\mathrm{Ca}^{2+}$-calmodulin-dependent form that is found

From the Department of Pharmacology and Toxicology, Virginia Commonwealth University, Medical College of Virginia, Richmond, Virginia.

Address correspondence to: Jenny L. Wiley, Ph.D., Department of Pharmacology and Toxicology, Virginia Commonwealth University, Medical College of Virginia, P.O. Box 980613, Richmond, Virginia 23298-0613.

Received August 7, 1997; accepted November 10, 1997. in the brain and is hypothesized to be involved in the centrally mediated properties of nitric oxide (Lambert et al. 1991). These central effects may include roles in memory formation (Chapman et al. 1992; Yamada et al. 1995), development of tolerance or sensitization to drugs of abuse (Khanna et al. 1993; Kolesnikov et al. 1992; Majeed et al. 1994; Pudiak and Bozarth 1993), and response to stroke or neurotrauma (Nagafusi et al. 1995; Schulz et al. 1995).

Although NOS is not completely co-localized with any known neurotransmitter, a subset of N-methyl-Daspartate (NMDA) neurons is associated with NOS (Garthwaite 1991). In these neurons, depolarization of the NMDA receptor by the endogenous excitatory amino acid neurotransmitter glutamate produces an influx of $\mathrm{Ca}^{2+}$ which binds to calmodulin. This $\mathrm{Ca}^{2+}$ calmodulin complex activates NOS directly, resulting in a brief "puff" of nitric oxide that diffuses out of the presynaptic terminal and into astrocytic processes to ac- 
tivate soluble guanylate cyclase (Garthwaite 1991); hence, nitric oxide may serve as an intracellular messenger that mediates glutamatergic effects at NMDA receptors. In addition, nitric oxide may also inhibit the actions of glutamate. Since nitric oxide is a gas that diffuses readily across cell membranes, its release may result in feedback inhibition of the presynaptic glutamate neuron via action at modulatory redox sites associated with NMDA receptors (Manzoni et al. 1992).

Consistent with the dual role of nitric oxide at NMDA receptors, previous research has shown that, although drugs that inhibit nitric oxide (NOS inhibitors) share some behavioral effects with NMDA antagonists, they also may attenuate other behaviors associated with NMDA antagonism. Shared properties include anxiolytic effects, memory impairment, and phencyclidine (PCP)-like discriminative stimulus effects (Chapman et al. 1992; Jewett et al. 1996; Volke et al. 1997). In contrast, Deutsch et al. (1996) found that NOS inhibitors blocked "popping" behavior in mice that was induced by the PCP-like noncompetitive NMDA antagonist, dizocilpine. Exploration of the effects of NOS inhibitors on other behavioral effects of NMDA antagonists, so far, has been minimal.

Another procedure in which PCP-like NMDA antagonists produce characteristic effects is prepulse inhibition of acoustic startle. The acoustic startle response is a reflexive movement that occurs upon abrupt presentation of a loud acoustic stimulus. Prepulse inhibition refers to a decrease in the magnitude of this startle response that is observed when the loud noise is preceded by a weak acoustic stimulus (a "prepulse"). Disruption of prepulse inhibition involves deficient capacity to "gate" or inhibit attention to incoming sensory information and occurs in certain disorders in humans such as schizophrenia, or can be induced by dopaminergic agonists or PCP-like noncompetitive NMDA antagonists in animals (Braff et al. 1978; Geyer et al. 1990). Previous research from this lab has shown that NOS inhibitors decreased startle amplitudes during pulse alone trials, but, unlike PCP, did not affect prepulse inhibition (Wiley et al. 1997).

The purpose of the present study was to examine the effects of NOS inhibitors on PCP-induced disruption of prepulse inhibition of the acoustic startle response in rats. The NOS inhibitors, $\mathrm{N}^{\mathrm{G}}$-nitro-L-arginine (L-NOARG), 7-nitroindazole, and arcaine, and their vehicles were tested alone and in combination with PCP. Since arcaine is not only a NOS inhibitor (Kabuto et al. 1995), but also an antagonist at the NMDA-associated polyamine site (Reynolds 1990), eliprodil was tested as a negative control in this study. Eliprodil shares arcaine's activity at NMDA-associated polyamine sites, but does not affect nitric oxide synthesis (Carter et al. 1989). A preliminary report of the results of this study was presented previously (Wiley 1997).

\section{METHODS}

\section{Animals}

Drug naive adult male Sprague-Dawley rats (weighing 225-249 $\mathrm{g}$ at the beginning of the study), obtained from Harlan (Dublin, VA), were individually housed in wire cages in a temperature-controlled $\left(20-22^{\circ} \mathrm{C}\right)$ environment with 12-hour light-dark cycle (lights on at 7 a.m.). Water and standard rodent chow were freely available in the home cages. Rats were weighed and handled daily for one week after initial date of delivery before testing began.

\section{Apparatus}

A clear Plexiglas cylinder (8.2 cm diameter) resting on a Plexiglas panel $(10 \times 20 \mathrm{~cm})$ was enclosed in each of three standard startle chambers (San Diego Instruments, San Diego, CA). Each chamber was illuminated by a 15watt houselight mounted in the ceiling above the cylinder. Acoustic stimuli were produced by a super tweeter, mounted $24 \mathrm{~cm}$ above the cylinder. An IBM-compatible computer with SR-Lab software and interface (San Diego Instruments) was used to present stimuli and to record data.

\section{Drugs}

L-NOARG (Research Biochemicals International, Natick, MA), arcaine sulfate (RBI), and phencyclidine (National Institute on Drug Abuse, Rockville, MD) were mixed in sterile water or physiological saline. 7-Nitroindazole (Sigma Chemicals, St. Louis, MO) was dissolved in dimethylsulfoxide (DMSO). Eliprodil (Synthelabo Recherche, Bagneux, France) was mixed in $0.1 \%$ Tween 80 and saline. L-NOARG (all doses) and eliprodil ( $3 \mathrm{mg} /$ $\mathrm{kg}$ ) were administered at a volume of $1 \mathrm{ml} / \mathrm{kg}$. Due to solubility-related issues, the $10 \mathrm{mg} / \mathrm{kg}$ dose of eliprodil was injected at a volume of $2 \mathrm{ml} / \mathrm{kg}$; the $10 \mathrm{mg} / \mathrm{kg}$ dose of arcaine, at a volume of $1.2 \mathrm{ml} / \mathrm{kg}$; and the $30 \mathrm{mg} / \mathrm{kg}$ dose of arcaine, at a volume of $3.6 \mathrm{ml} / \mathrm{kg}$. 7-Nitroindazole (all doses) was given at a volume of $0.5 \mathrm{ml} / \mathrm{kg}$. The NOS inhibitors, eliprodil, and their vehicles were injected i.p. $30 \mathrm{~min}$ before the start of the startle session. Phencyclidine or saline was injected s.c. at a volume of $1 \mathrm{ml} / \mathrm{kg} 20 \mathrm{~min}$ pre-session.

\section{Procedure}

Rats were transported to the laboratory at least $30 \mathrm{~min}$ before startle sessions. After being injected with the test drugs, they were returned to their home cages for the remainder of the pre-session injection interval. Before the start of the startle session, rats were placed in the startle chambers for a five-min adaptation period, during which they were exposed to $69 \mathrm{~dB}[\mathrm{~A}]$ background 
noise. This background noise continued throughout the session. Each startle session consisted of 61 trials (average intertrial interval $=15 \mathrm{sec}$ ). During the first trial, rats were exposed to a $120 \mathrm{~dB}[\mathrm{~A}]$ acoustic stimulus. Subsequent trials were of four types, presented in mixed order, for a total session duration of approximately $20 \mathrm{~min}$. On one type of trial, the rats were exposed to a $120 \mathrm{~dB}[\mathrm{~A}]$ acoustic stimulus (pulse trials). Startle amplitudes during these trials indicates the degree of sensorimotor reactivity. A second type of trial consisted of an $85 \mathrm{~dB}[\mathrm{~A}]$ prepulse (20 msec duration) followed by $120 \mathrm{~dB}[\mathrm{~A}]$ pulse (prepulse + pulse trials). The degree to which startle amplitudes during this type of trial was decreased as compared to responding during the $120 \mathrm{~dB}[\mathrm{~A}]$ pulse alone trials is a measure of prepulse inhibition or sensorimotor gating. The other two types of trials consisted of exposure to an $85 \mathrm{~dB}[\mathrm{~A}]$ prepulse alone (prepulse trials) or to $69 \mathrm{~dB}[\mathrm{~A}]$ background noise (nostim trials). Startle amplitudes during these trials were typically very low. These trials were control trials used to measure the degree of "noise" in the procedure. A startle session was comprised of a first trial and five trials of each of the four types. Startle pulse duration was held constant at $40 \mathrm{msec}$. A $100 \mathrm{msec}$ delay was imposed between prepulse and pulse stimuli.

The dose-effect curves for 7-nitroindazole, arcaine and eliprodil were determined in a within-subjects design with 12 rats per drug. L-NOARG was tested in two groups of 12 rats each. The first group received vehicle, 1 and $3 \mathrm{mg} / \mathrm{kg}$ L-NOARG with and without PCP; the second group received vehicle, 10 and $30 \mathrm{mg} / \mathrm{kg}$ L-NOARG with and without PCP. Data from both groups were combined for the purposes of data analysis. A 3 $\mathrm{mg} / \mathrm{kg}$ dose of PCP was used in all studies. In order to minimize the confound potentially produced by habituation or carry-over effects, the order of dose combinations was randomized across the rats in each group, according to a Latin Square design. At least $72 \mathrm{hrs}$ intervened between test sessions for each rat.

\section{Data Analysis}

Startle score was defined as the average of 1001 -msec voltage readings. Prepulse inhibition was calculated for prepulse + pulse trials as a percentage of pulse alone scores [(mean startle amplitude for pulse alone trials mean startle amplitude for prepulse + pulse trials)/ mean startle amplitude for pulse alone trials] $\times 100$. For each dose-effect curve, separate two-factor (PCP vs. saline $\times$ drug dose) repeated measures GLM procedures (SAS Institute, Cary, NC) were used to analyze percent prepulse inhibition and average startle amplitudes during pulse alone trials. Tukey post-hoc tests $(\alpha=0.05)$ were used to specify differences revealed by significant GLM's. (Startle amplitudes during prepulse alone trials and during trials in which there was not any auditory stimulation were consistently low and are not shown.)

\section{RESULTS}

\section{Effects of NOS Inhibitors on PCP-Induced Disruption of Prepulse Inhibition of the Acoustic Startle Response}

Figures 1 and 2 show the effects of tests with the NOS inhibitors, L-NOARG and 7-nitroindazole, alone and in combination with $3 \mathrm{mg} / \mathrm{kg}$ PCP on startle amplitudes during pulse alone trials (upper panels) and on \% prepulse inhibition (lower panels). Startle amplitudes during pulse alone trials did not differ significantly across conditions for L-NOARG (Figure 1, upper panel), but were decreased by each dose of 7-nitroindazole [main effect $F(2,22)=6.32, p=.007]$. In each group of rats, PCP $(3 \mathrm{mg} / \mathrm{kg})$ disrupted prepulse inhibition compared to vehicle conditions $[F(1,23)=84.57, p=$ .0001 and $F(1,23)=90.53, p=.001$, respectively], and there were significant interactions between PCP condition and NOS inhibitor dose on degree of prepulse inhibition $[F(4,44)=2.93, p=.03$ and $F(2,21)=7.95, p=$ .003 , respectively]. While PCP $(3 \mathrm{mg} / \mathrm{kg}$ ) disrupted prepulse inhibition (compared to the saline/vehicle condition) across every dose of L-NOARG or 7-nitroindazole, the degree of disruption varied dependent upon dose of NOS inhibitor. L-NOARG dose-dependently attenuated the effect produced by PCP on prepulse inhibition with significant reversal occurring at a dose of 30 $\mathrm{mg} / \mathrm{kg}$ L-NOARG (compared to saline/PCP condition; Figure 1, lower panel). Similarly, a $10 \mathrm{mg} / \mathrm{kg}$ dose of 7-nitroindazole significantly increased the degree of prepulse inhibition following PCP administration (compared to saline/PCP condition), although a higher dose failed to do so (Figure 2, lower panel).

\section{Effects of Polyamine Site NMDA Antagonists on PCP-Induced Disruption of Prepulse Inhibition of the Acoustic Startle Response}

Figures 3 and 4 show the effects of tests with the polyamine site NMDA antagonists, arcaine and eliprodil, alone and in combination with $3 \mathrm{mg} / \mathrm{kg}$ PCP on startle amplitudes during pulse alone trials (upper panels) and on \% prepulse inhibition (lower panels). Startle amplitudes during pulse alone trials were decreased by $30 \mathrm{mg} / \mathrm{kg}$ of arcaine [main effect $F(2,22)=3.67, p=.04$ ], but did not differ significantly across conditions for eliprodil (Figures 3 and 4, upper panels). Disruption of prepulse inhibition by $3 \mathrm{mg} / \mathrm{kg}$ of PCP occurred in each group of rats (Figures 3 and 4, lower panels). While a 10 $\mathrm{mg} / \mathrm{kg}$ dose of arcaine failed to alter the effect produced 

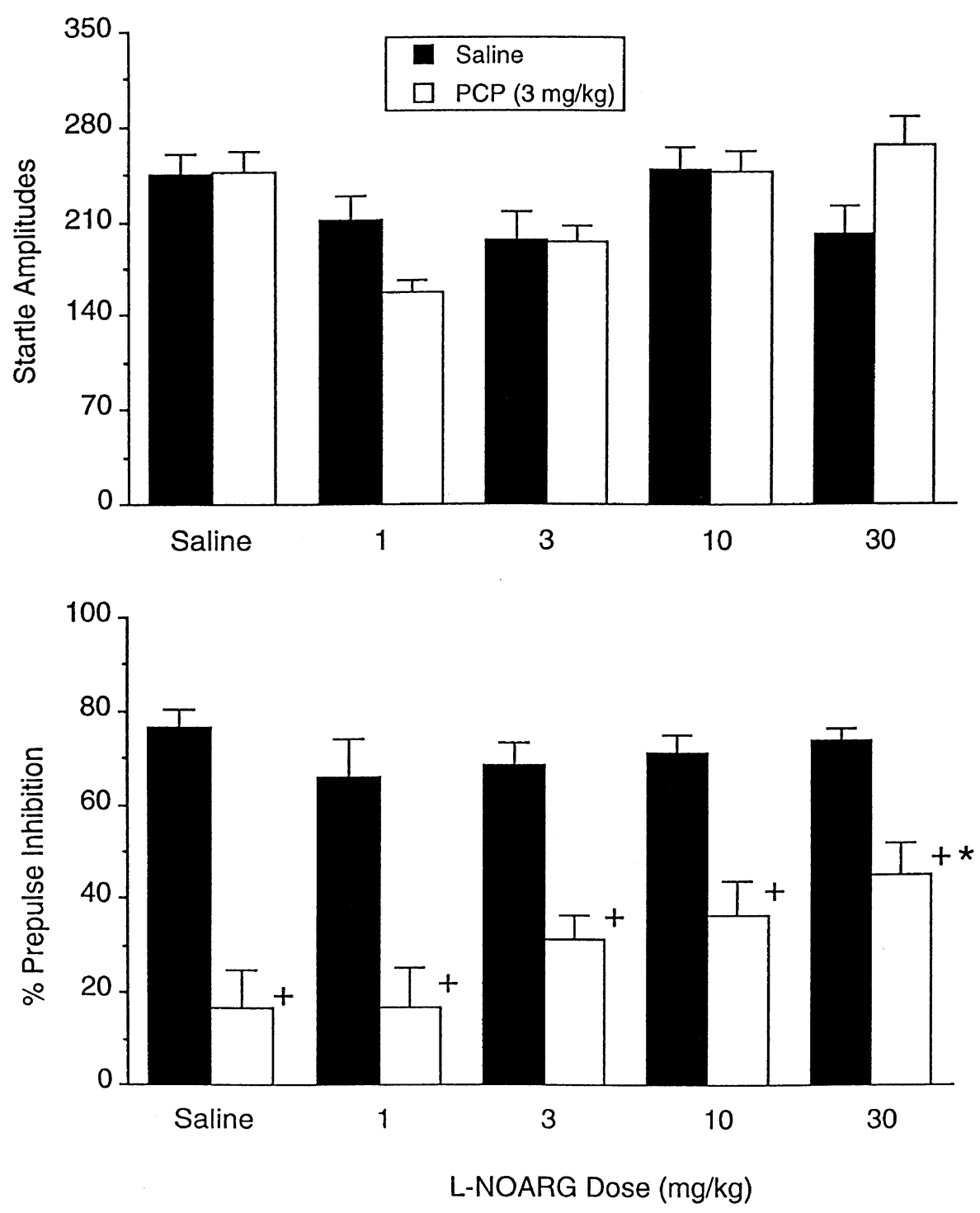

Figure 1. Effects of L-NOARG (NOS inhibitor) alone and in combination with $3 \mathrm{mg} / \mathrm{kg}$ PCP on startle amplitudes during pulse alone trials (upper panel) and on \% prepulse inhibition (lower panel). Each bar represents the mean $( \pm S E M)$ of data from 12 (each L-NOARG dose with saline or PCP) or 24 (saline/ saline and saline/PCP conditions) rats. $+p<.05$ compared to sal/sal; ${ }^{*} p<.05$ compared to sal/PCP. by PCP, a $30 \mathrm{mg} / \mathrm{kg}$ dose of arcaine completely reversed the PCP-induced disruption of prepulse inhibition [interaction $F(2,22)=13.55, p=.0001]$. The degree of PCP-induced disruption of prepulse inhibition was not affected by either dose of eliprodil; i.e., there was a significant main effect for PCP vs. saline $[F(1,11)=333.87$, $p=.001]$, but no significant interaction.

\section{DISCUSSION}

The results of the present study showed that, when the NOS inhibitors, L-NOARG, 7-nitroindazole, or arcaine, were injected prior to PCP administration, each drug reduced PCP-induced disruption of prepulse inhibition. Although arcaine produced complete blockade of PCPinduced disruption of prepulse inhibition, L-NOARG and 7-nitroindazole only partially attenuated the effect produced by PCP on prepulse inhibition. At least a lim- ited degree of selectivity of this attenuation was suggested by the fact that, the NR2B-selective polyamine site NMDA antagonist, eliprodil, failed to alter PCPinduced disruption of prepulse inhibition. Since eliprodil did not show obvious behavioral activity in the present study, it is possible that a higher dose might have affected PCP-induced disruption of prepulse inhibition in a manner similar to arcaine. This possibility is unlikely, however, as doses of 10 or $30 \mathrm{mg} / \mathrm{kg}$ eliprodil failed to alter the effects of $1 \mathrm{mg} / \mathrm{kg}$ PCP in a similar model, although the $30 \mathrm{mg} / \mathrm{kg}$ dose decreased startle amplitudes during pulse alone trials (unpublished data). The present results confirm and extend a previous finding that the NOS inhibitor, L-NAME, blocked disruption of prepulse inhibition induced by a $2 \mathrm{mg} / \mathrm{kg}$ dose of PCP (Johansson et al. 1997). In that study, pharmacological selectivity was suggested by the fact that L-NAME did not alter amphetamine-induced disruption of prepulse inhibition. 

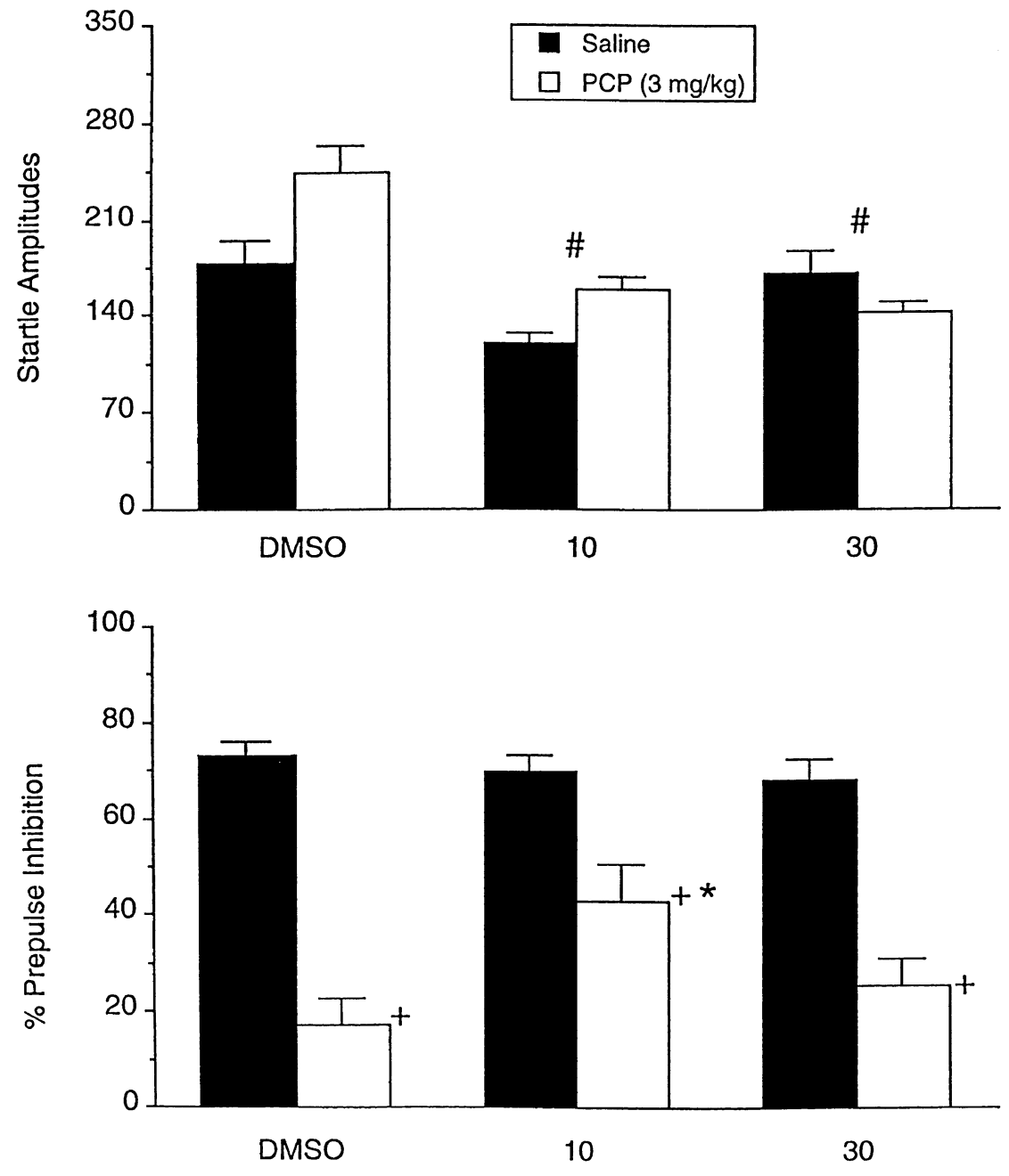

7-Nitroindazole Dose (mg/kg)
Figure 2. Effects of 7-nitroindazole (NOS inhibitor) alone and in combination with $3 \mathrm{mg} / \mathrm{kg}$ PCP on startle amplitudes during pulse alone trials (upper panel) and on \% prepulse inhibition (lower panel). Each bar represents the mean $( \pm$ SEM) of data from 12 rats. $+p<.05$ compared to DMSO/ sal; ${ }^{*}<.05$ compared to DMSO/PCP; $\# p<.05$ main effect for 7-nitroindazole dose.
A review of preclinical research examining pharmacological effects of NOS inhibitors reveals conflicting results. While some studies have reported that NOS inhibitors share behavioral effects with NMDA antagonists, including anxiolytic, anticonvulsant, and neuroprotective effects (Nagafusi et al. 1995; Volke et al. 1997), other studies have found that NOS inhibitors either do not mimic (Stewart et al. 1994; Wiley et al. 1995, 1997) and/or attenuate (Deutsch et al. 1996; Johansson et al. 1997) the effects of NMDA antagonists. For example, recent studies have shown that NOS inhibitors block the effects of PCP-like NMDA antagonists on "popping" behavior in mice (Deutsch et al. 1996) and locomotor activity and prepulse inhibition of the acoustic startle response in rats (Johansson et al. 1997). Potentiation of NMDA-induced neurotoxicity by 7-nitroindazole has also been reported (Connop et al. 1994). Although task and species variation across studies may play a role in differences in results obtained with these drugs, it is possible that the dual role of nitric oxide as an intracellular messenger and as a retrograde messenger at the NMDA receptor complex may also help account for the divergent findings. Hence, NOS inhibitors may have both excitatory and inhibitory influences on NMDA receptor-associated events. In fact, Rundfeldt et al. (1995) have shown that the propensity of NOS inhibitors to produce anticonvulsant vs. proconvulsant effects in the same seizure model is dependent upon dose and time of administration. Although 7-nitroindazole was not tested in this seizure model, it showed a similar biphasic pattern of effects in the present study, in that a $10 \mathrm{mg} / \mathrm{kg}$ dose attenuated PCP-induced disruption of prepulse inhibition whereas a $30 \mathrm{mg} / \mathrm{kg}$ dose did not. Previous research has shown that this dose range of 7-nitroindazole is consistent with that which produces maximal inhibition of NOS in the brains of rats following acute i.p. injection (Connop et al. 1994).

To date, however, the effects of NOS inhibitors in the acoustic startle model have been consistent: without exception, this class of drugs have no effect on prepulse 

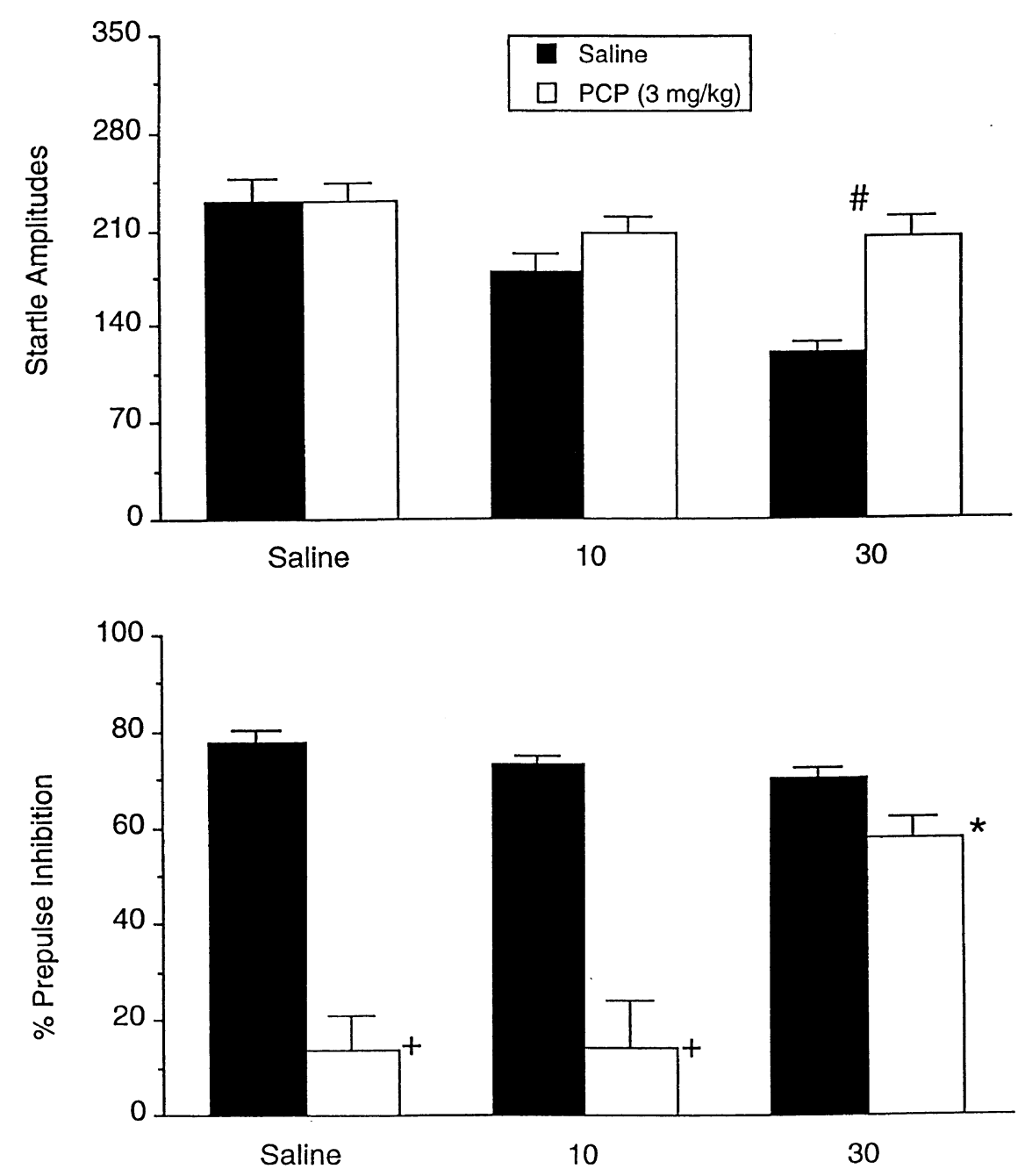

Arcaine Dose (mg/kg)
Figure 3. Effects of arcaine (NOS inhibitor and polyamine site NMDA antagonist) alone and in combination with $3 \mathrm{mg} / \mathrm{kg}$ PCP on startle amplitudes during pulse alone trials (upper panel) and on \% prepulse inhibition (lower panel). Each bar represents the mean $( \pm \mathrm{SEM})$ of data from 12 rats. $+p<.05$ compared to $\mathrm{sal} / \mathrm{sal} ;{ }^{*} p<.05$ compared to sal/ PCP; \# $p<.05$ main effect for arcaine dose. inhibition when administered alone, but attenuate PCPinduced disruption of prepulse inhibition (Johansson et al. 1997; Wiley et al. 1997). The only other class of drugs that has been shown to have a similar effect on PCPinduced disruption of prepulse inhibition is antipsychotics. Atypical antipsychotics (those that do not produce the motor impairment associated with typical antipsychotics such as haloperidol), including clozapine, olanzapine, and seroquel, reverse the disruptive effect produced by PCP on prepulse inhibition (Bakshi and Geyer 1995; Bakshi et al. 1994; Swerdlow et al. 1996), although there are exceptions (Hoffman et al. 1993; Johansson et al. 1994; Wiley 1994). These drugs also block the disruptive effects of dopamine agonists on prepulse inhibition (Swerdlow and Geyer 1993; Swerdlow et al. 1991, 1994) (L-NAME does not; Johansson et al. 1997). In contrast, haloperidol, a high potency typical antipsychotic, blocks amphetamine- or apomorphine-induced disruption of prepulse inhibition (Mansbach et al. 1988; Swerdlow and Geyer 1993), but does not alter PCP-induced effects in this paradigm (Keith et al. 1991). Ellenbroek and Cools (1990) have suggested that prepulse inhibition of acoustic startle represents a valid animal model of attentional deficits that are present in schizophrenia. Hence, the present results suggest that additional investigation of the potential utility of NOS inhibitors as antipsychotics may be warranted.

Other types of evidence have strongly implicated nitric oxide in schizophrenia. First, nitric oxide is intimately connected with dopamine and glutamate, two neurotransmitter systems that are dysfunctional in schizophrenia (Lonart et al. 1993; Montague et al. 1994; Pogun et al. 1994). Further, nitric oxide's dual action as mediator and negative modulator of glutamate neurotransmission at the NMDA receptor complex give this system a unique role in regulating the balance of excitatory and inhibitory influences. It is this balance of excitatory and inhibitory processes that is likely to be 

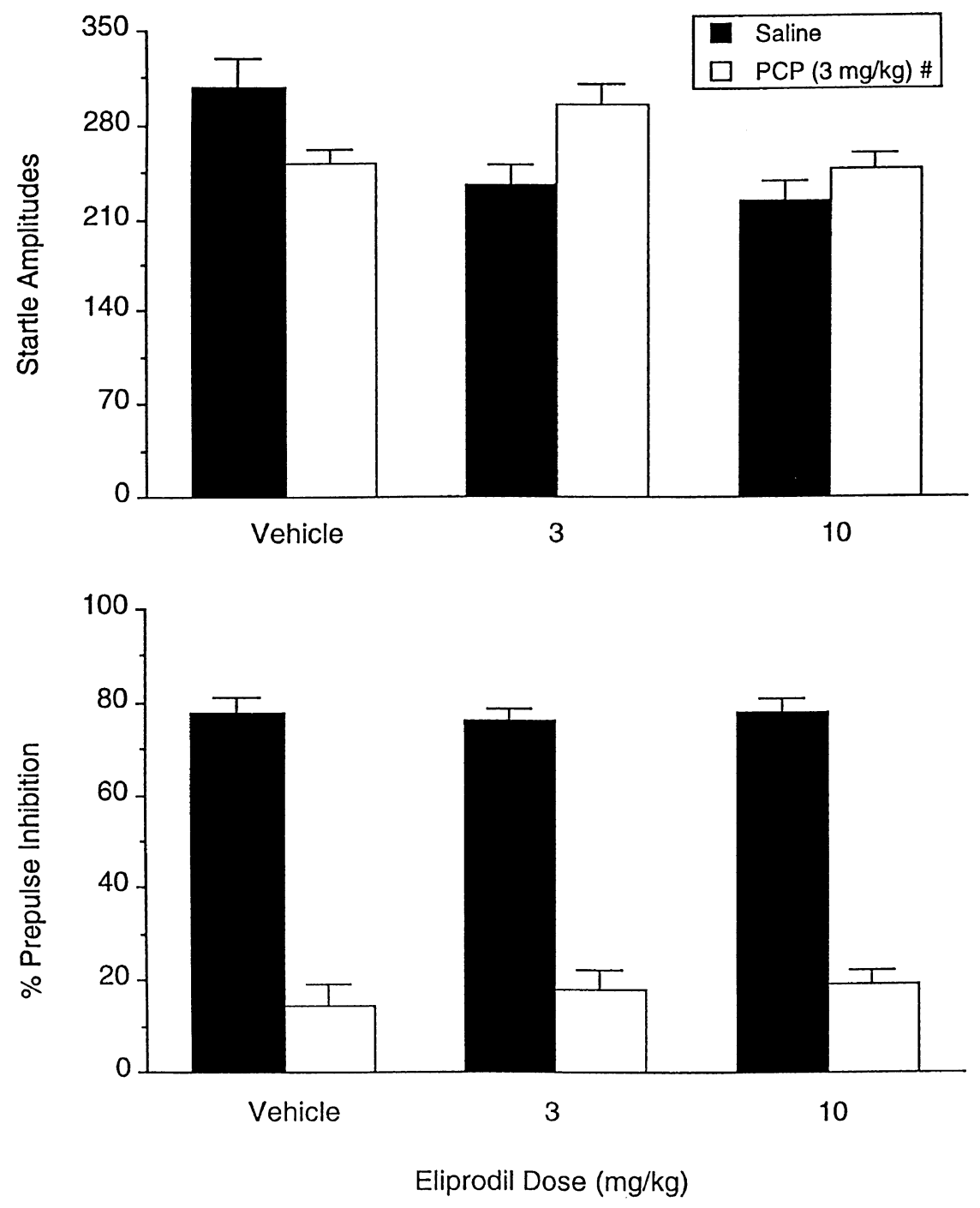

Figure 4. Effects of eliprodil (NR2Bselective, polyamine site NMDA antagonist) alone and in combination with $3 \mathrm{mg} / \mathrm{kg}$ PCP on startle amplitudes during pulse alone trials (upper panel) and on \% prepulse inhibition (lower panel). Each bar represents the mean $( \pm$ SEM) of data from 12 rats. \# $p<.05$ main effect for PCP (vs. saline). disrupted in schizophrenia, as proposed by glutamate hypofunction and GABA predominance theories of this disorder (Squires and Saederup 1991). A second line of evidence that suggests a role for nitric oxide in schizophrenia is the finding that measures of nitric oxide metabolism are altered in platelets or postmortem brains of schizophrenic patients (Akbarian et al. 1993a,b; Das et al. 1995; Karson et al. 1991). Third, preliminary studies suggest that antipsychotics may decrease synthesis of nitric oxide (Hu et al. 1994).

In summary, attenuation of PCP-induced disruption of prepulse inhibition by NOS inhibitors is similar to the effects produced in this procedure by several antipsychotics. Consistent with the findings of previous studies which have reported that NOS inhibitors block characteristic behaviors produced by PCP-like drugs, the present results suggest that NOS inhibitors may counteract some of the effects of PCP-induced glutamate hypoactivity. However, given that the behavioral effects of NOS inhibitors mimic those of PCP-like drugs in other preclinical procedures, further investigation of this class of drugs for potential utility as antipsychotics and as treatments for PCP abuse should proceed, but with caution.

\section{ACKNOWLEDGMENTS}

This work was supported by the Grant-In-Aid Program for Faculty of Virginia Commonwealth University and by National Institute on Drug Abuse grant DA-01442. The technical assistance of David Arthur, Inna Bespalova, and James Hyman is gratefully acknowledged. Eliprodil was provided as a gift from David Sanger of Synthelabo Recherche (Bagneux, France). 


\section{REFERENCES}

Akbarian S, Bunney WE, Potkin SG, Wigal SB, Hagman JO, Sandman CA, Jones EG (1993a): Altered distribution of nicotinamide-adenine dinucleotide phosphate-diaphorase cells in frontal lobe of schizophrenics implies disturbances of cortical development. Arch Gen Psychiat 50:169-177

Akbarian S, Vinuela A, Kim JJ, Potkin SG, Bunney WE, Jones EG (1993b): Distorted distribution of nicotinamide-adenine dinucleotide phosphate-diaphorase neurons in temporal lobe of schizophrenics implies anomalous cortical development. Arch Gen Psychiat 50:178-187

Bakshi VP, Geyer MA (1995): Antagonism of phencyclidineinduced deficits in prepulse inhibition by the putative atypical antipsychotic olanzapine. Psychopharmacology 122:198-201

Bakshi VP, Swerdlow NR, Geyer MA (1994): Clozapine antagonizes phencyclidine-induced deficits in sensorimotor gating of the startle response. J Pharmacol Exp Ther 271:787-794

Braff D, Stone C, Callaway E, Geyer M, Glick I, Bali L (1978): Prestimulus effects on human startle reflex in normals and schizophrenics. Psychophysiology 15:339-343

Carter C, Rivy JP, Scatton B (1989): Ifenprodil and SL 82.0715 are antagonists at the polyamine site of the N-methyl-Daspartate (NMDA) receptor. Eur J Pharmacol 164:611612

Chapman PF, Atkins CM, Allen MT, Haley JE, Steinmetz JE (1992): Inhibition of nitric oxide synthesis impairs two different forms of learning. NeuroReport 3:567-570

Connop BP, Rolfe NG, Boegman RJ, Jhamandas K, Beninger RJ (1994): Potentiation of NMDA-mediated toxicity on nigrostriatal neurons by a low dose of 7-nitro indazole. Neuropharmacology 33:1439-1445

Das I, Khan NS, Puri BK, Sooranna SR, de Belleroche J, Hirsch SR (1995): Elevated platelet calcium mobilization and nitric oxide synthase activity may reflect abnormalities in schizophrenic brain. Biochem Biophys Res Comm 22:375-380

Deutsch SI, Rosse RB, Paul SM, Tomasino V, Koetzner L, Morn CB, Mastropaolo J (1996): 7-Nitroindazole and methylene blue, inhibitors of neuronal nitric oxide synthase and NO-stimulated guanylate cyclase, block MK801-elicited behaviors in mice. Neuropsychopharmacology 15:37-43

Ellenbroek BA, Cools AR (1990): Animal models with construct validity for schizophrenia. Behav Pharmacol 1:469-490

Garthwaite J (1991): Glutamate, nitric oxide and cell-cell signalling in the nervous system. Tr Neurosci 14:60-67

Geyer MA, Swerdlow NR, Mansbach RS, Braff DL (1990): Startle response models of sensorimotor gating and habituation deficits in schizophrenia. Brain Res Bull 25:485-498

Hoffman DC, Donovan H, Cassella JV (1993): The effects of haloperidol and clozapine on the disruption of sensorimotor gating induced by the noncompetitive glutamate antagonist MK-801. Psychopharmacology 111:339-344

$\mathrm{Hu}$ J, Lee JH, El-Fakahany EE (1994): Inhibition of neuronal nitric oxide synthase by antipsychotic drugs. Psychopharmacology 114:161-166

Jewett DC, Butelman ER, Woods JH (1996): Nitric oxide synthase inhibitors produce phencyclidine-like behavioral effects in pigeons. Brain Res 715:25-31

Johansson C, Jackson DM, Svensson L (1994): The atypical antipsychotic, remoxipride, blocks phencyclidine-induced disruption of prepulse inhibition in the rat. Psychopharmacology 116:437-442

Johansson C, Jackson DM, Svensson L (1997): Nitric oxide synthase inhibition blocks phencyclidine-induced behavioural effects on prepulse inhibition and locomotor activity in the rat. Psychopharmacology 131:167-173

Kabuto H, Yokoi I, Habu H, Asahara H, Mori A (1995): Inhibitory effect of arcaine on nitric oxide synthase in the rat brain. NeuroReport 6:554-556

Karson CN, Garcia-Rill E, Biedermann J, Mrak RE, Husain MM, Skinner RD (1991): The brain stem reticular formation in schizophrenia. Psychiat Res Neuroimag 40:31-48

Keith VA, Mansbach RS, Geyer MA (1991): Failure of haloperidol to block the effects of phencyclidine and dizocilpine on prepulse inhibition of acoustic startle. Biol Psychiatr 30:557-566

Khanna JM, Morato GS, Shah G, Chau A, Kalant H (1993): Inhibition of nitric oxide synthesis impairs rapid tolerance to ethanol. Brain Res Bull 32:43-47

Kolesnikov YA, Pick CG, Pasternak GW (1992): NG-nitroL-arginine prevents morphine tolerance. Eur J Pharmacol 221:399-400

Lambert LE, Whitten JP, Baron BM, Cheng HC, Doherty NS, McDonald IA (1991): Nitric oxide in the CNS, endothelium and macrophages differs in its sensitivity to inhibition by arginine analogues. Life Sci 48:69-75

Lonart G, Cassels KL, Johnson KM (1993): Nitric oxide induces calcium-dependent $\left[{ }^{3} \mathrm{H}\right]$ dopamine release from striatal slices. J Neurosci Res 35:192-198

Majeed NH, Przewlocka B, Machelska H, Przewlocki R (1994): Inhibition of nitric oxide synthase attenuates the development of morphine tolerance and dependence in mice. Neuropharmacology 33:189-192

Mansbach RS, Geyer MA, Braff DL (1988): Dopaminergic stimulation disrupts sensorimotor gating in the rat. Psychopharmacology 94:507-514

Manzoni O, Prezeau L, Marin P, Deshager S, Bockaert J, Fagni L (1992): Nitric oxide-induced blockade of NMDA receptors. Neuron 8:653-662

Montague PR, Gancayco CD, Winn MJ, Marchase RB, Friedlander MJ (1994): Role of NO production in NMDA receptor-mediated neurotransmitter release in cerebral cortex. Science 263:973-977

Nagafusi T, Sugiyama M, Muto A, Makino T, Miyauchi T, Nabata H (1995): The neuroprotective effect of a potent and selective inhibitor of type I NOS (L-MIN) in a rat model of focal cerebral ischaemia. NeuroReport 6:15411545

Pogun S, Baumann MH, Kuhar MJ (1994): Nitric oxide inhibits $\left[{ }^{3} \mathrm{H}\right]$ dopamine uptake. Brain Res 641:83-91

Pudiak CM, Bozarth MA (1993): L-NAME and MK-801 attenuate sensitization to the locomotor-stimulating effects of cocaine. Life Sci 53:1517-1524 
Reynolds IJ (1990): Arcaine is a competitive antagonist of the polyamine site on the NMDA receptor. Eur J Pharmacol 177:215-216

Rundfeldt C, Koch R, Richter A, Mevissen M, Gerecke U, Loscher W (1995): Dose-dependent anticonvulsant and proconvulsant effects of nitric oxide synthase inhibitors on seizure threshold in a cortical stimulation model in rats. Eur J Pharmacol 274:73-81

Schulz JB, Matthews RT, Muqit MMK, Browne SE, Beal MF (1995): Inhibition of neuronal nitric oxide synthase by 7-nitroindazole protects against MPTP-induced neurotoxicity in mice. J Neurochem 64:936-939

Squires RF, Saederup E (1991): A review of evidence for GABergic predomininace/glutamatergic deficit as a common etiological factor in both schizophrenia and affective psychoses: More support for a continuum hypothesis of "functional" psychosis. Neurochem Res 16:1099-1111

Stewart J, Deschamps SE, Amir S (1994): Inhibition of nitric oxide synthase does not block development of sensitization to the behavioral activating effects of amphetamine. Brain Res 641:141-144

Swerdlow NR, Geyer MA (1993): Clozapine and haloperidol in an animal model of sensorimotor gating deficits in schizophrenia. Pharmacol Biochem Behav 44:741-744

Swerdlow NR, Bakshi V, Geyer MA (1996): Seroquel restores sensorimotor gating in phencyclidine-treated rats. J Pharmacol Exp Ther 279:1290-1299

Swerdlow NR, Keith VA, Braff DL, Geyer MA (1991): Effects of spiperone, raclopride, SCH 23390 and clozapine on apomorphine inhibition of sensorimotor gating of the startle response in the rat. J Pharmacol Exp Ther 256:530-536

Swerdlow NR, Zisook D, Taaid N (1994): Seroquel (ICI $204,636)$ restores prepulse inhibition of acoustic startle in apomorphine-treated rats: Similarities to clozapine. Psychopharmacology 114:675-678

Volke V, Soosaar A, Koks S, Bourin M, Mannisto PT, Vasar E (1997): 7-Nitroindazole, a nitric oxide synthase inhibitor, has anxiolytic-like properties in exploratory models of anxiety. Psychopharmacology 131:399-405

Wiley JL (1994): Clozapine's effects on phencyclidineinduced disruption of prepulse inhibition of the acoustic startle response. Pharmacol Biochem Behav 49:10251028

Wiley JL (1997): NOS inhibitors attenuate PCP-induced disruption of prepulse inhibition. Pharmacol Biochem Behav 57:623

Wiley JL, Cristello AF, Balster RL (1995): Effects of site-selective NMDA antagonists in an elevated plus-maze model of anxiety in mice. Eur J Pharmacol 294:101-107

Wiley JL, Golden KM, Bowen SE (1997): Effects of modulation of nitric oxide on acoustic startle responding and prepulse inhibition in rats. Eur J Pharmacol 328:125-130

Yamada K, Noda Y, Nakayama S, Komori Y, Sugihara H, Hasegawa T, Nabeshima T (1995): Role of nitric oxide in learning and memory and in monoamine metabolism in the rat brain. Br J Pharmacol 115:852-858 